Multiplicités des approches en anglais de spécialité

\title{
Teaching ESP: A task-based framework for French graduate courses
}

\section{Shona Whyte}

\section{(2) OpenEdition \\ 1 Journals}

\section{Electronic version}

URL: http://journals.openedition.org/asp/3280

DOI: $10.4000 /$ asp.3280

ISSN: 2108-6354

\section{Publisher}

Groupe d'étude et de recherche en anglais de spécialité

\section{Printed version}

Date of publication: 1 March 2013

Number of pages: 5-30

ISSN: 1246-8185

\section{Electronic reference}

Shona Whyte, «Teaching ESP: A task-based framework for French graduate courses », ASp [Online] 63 | 2013, Online since 07 October 2014, connection on 10 December 2020. URL : http:// journals.openedition.org/asp/3280; DOI : https://doi.org/10.4000/asp.3280

This text was automatically generated on 10 December 2020 .

Tous droits réservés 


\title{
Teaching ESP: A task-based framework for French graduate courses
}

\author{
Shona Whyte
}

\section{Introduction}

1 The type of teaching and learning broadly described as English for Specific Purposes (ESP) is generally viewed quite differently by second language researchers and by postsecondary language teachers. Research in second language acquisition over the past forty years (i.e., since Selinker 1972) has highlighted similarities in the process and product of second language acquisition across learners with different backgrounds, aptitudes and exposure, and in varied contexts (e.g., mode, interlocutor or topic). In the second language classroom, on the other hand, teachers are aware of the differing needs and expectations of language learners who aim to work in business, education, or academic research, to name but three possibilities. ESP learners do need to develop domain-specific competence in relation to particular discourse events and must also integrate communities of practice relevant to their future professional lives. How, then, are these two views to be reconciled? One avenue is task-based language teaching (TBLT). Tasks in language teaching were initially the focus of cognitively-oriented research (Ellis 2003; Skehan 2003a, 2003b) and TBLT has received much recent attention from researchers and teacher trainers (Samuda \& Bygate 2008; Guichon \& Nicolaev 2011). TBLT has been a particular focus of research in language learning and teaching with technologies (Bertin, Gravé \& Narcy Combes 2010; Thomas \& Reinders 2010a), and the methodological principles outlined for computer-mediated language teaching by Doughty \& Long (2003) have been especially influential in this area.

2 The paper begins with a review of research literature on second language research in topic-related variation, ESP, and task-based learning and teaching. The body of the paper then addresses the design of task-based curricula for advanced learners in 
French university contexts, using Doughty and Long's (2003) framework for the design, implementation, and analysis of task-based activities in three different graduate ESP courses: English for International Business (master finance-management), English for Science Teachers (master enseignement physique-chimie), and English for Research Purposes (anglais pour doctorants en lettres et sciences humaines).

\section{Theory and method in teaching ESP}

Second language (L2) research has long established both systematicity and variation as key characteristics of second language development (Larsen-Freeman \& Long 1991; Mitchell \& Myles 2002). Learners' language, or interlanguage (IL) (Selinker 1972), has been shown to follow predictable developmental patterns irrespective of individual learner characteristics, such as first language, or learning context (instructed versus untutored settings). On the other hand, learners also show variation in second language production depending on factors such as mode, topic, interlocutor or other aspects of context. Researchers differ in the relative importance they give to the systematic and variable aspects of L2 development. For Long, the only worthwhile object of study is learners' cognitive processes during acquisition: "Remove a learner from the social setting, and the L2 grammar does not change or disappear" (1998: 93). Others, however,

view the learner as a social being whose cognitive processing of the L2 is affected by social interactions and social relationships with others, including those others who provide L2 input and corrective feedback. (Tarone 2007: 840)

4 The field of English for Specific Purposes falls naturally into this second research focus, predicated as it is on a view of language teaching and learning which is differentiated according to discourse area and learning objectives. One area of interlanguage variation research which addresses these challenges as they affect second language development is the discourse domain hypothesis (Selinker \& Douglas 1985; Douglas \& Selinker 1985).

\subsection{Second language effects for topic expertise}

5 The concept of discourse domain was originally proposed as "a personally, and internally created 'slice' of one's life that has importance and over which the learner exercises content-control" (Douglas \& Selinker 1985: 206). Discourse domains are "internally created contexts [...] within which IL structures are created differentially" (Selinker \& Douglas 1985: 190). The notion of discourse domain speaks to teachers' and learners' intuitive expectations that learners' particular expertise and investment in a given topic at a particular time will influence their language competence. Empirical support for discourse domains effects in interaction such as longer turns and greater IL complexity are reviewed in Chang (2008).

6 A more elaborated definition of the discourse domain construct was developed by Whyte $(1994,1995)$ :

A discourse domain is a topic area that is characterised by extensive knowledge (for which speakers possess an elaborated schema, and which they control completely), by important knowledge (which is central to speakers' networks of schemata, and in which they are invested), and by current knowledge (which speakers use frequently in interaction, and with which they are familiar). (Whyte 1995: 158) 
7 This study, however, provides only limited support for the discourse domain construct, which other variationists attribute to an overly narrow definition of the discourse, suggesting that interactional factors, such as the influence of the speakers' interlocutors, must also be taken into account (Young 1999; Douglas 2004).

Douglas's most recent definition of discourse domain retains Whyte's three dimensions and situates the concept firmly within learners' communicative competence:

A discourse domain is a cognitive construct within which a language is developed and used. Discourse domains are developed in relation to context, as defined by setting, participants, purpose, content, tone, language, norms of interaction, and genre. They are created as part of communicative competence along three dimensions: the extent of content knowledge, its importance in the life of the user, and the currency of the knowledge in interaction. Discourse domains are dynamic and changing, and vary in strength depending on the amount and quality of experience associated with particular communicative situations. (Douglas 2004: 34)

Douglas distinguishes between what he considers to be the undeniable effect of discourse domains on second language interaction and their more questionable influence on second language development. Following Tarone (2000), Douglas admits that "there are serious questions about whether context affects the acquisition process and/or the resulting interlanguage grammar at all" (Douglas 2004: 25). He enumerates several contextual features (setting, participants, purpose) to be taken into account in teaching and testing, and calls for further discourse domain research using corpusbased methods and introspective data as teachers and researchers "continue to wrestle with context" (2004: 41). Second language theory concerning language development with respect to domains of discourse therefore emphasises the complexity of this issue and hence the difficulties inherent in its application to language teaching.

\subsection{Research-based language education}

10 Just as second language researchers may argue that interlanguage development involves cognitive processes which occur independently of social context and result in a unitary, individual language competence existing inside each learner's mind, so too some educators quoted in Hyland (2002) contend that "there are generic skills and forms of language that are the same across a range of disciplines, professions, or purposes" (Hyland 2002: 387) and that "ESP involves teaching general skills and forms that are transferable across contexts and purposes" (Hyland 2002: 389). In contrast, Hyland himself makes a strong case for the specificity of ESP instruction. He categorises ESP as "research-based language education" and particularly values its "grounded insights into the structures and meanings of texts, the demands placed by academic or workplace contexts on communicative behaviours, and the pedagogic practices by which these behaviours can be developed" (Hyland 2002: 386). For Hyland, ESP therefore requires research into the particular practices of different discourse communities as well as consideration of how learners can best be brought to understand and develop these practices themselves (see also Dudley-Evans 2001). However, ESP classes do not always include learners with a homogeneous set of skills, needs and objectives. Hyland seeks to turn this challenge into an opportunity, urging teachers to allow students to "contrast their disciplinary experiences and expectations" and so understand "the multi-literate nature of the academy" (2002: 393). 


\subsection{Task-based approaches to language teaching}

11 Task-based language teaching owes much of its theoretical foundation to Long (1989) and Skehan (2003a, 2003b), and its practical classroom implementation, particularly in English language teaching, to Ellis $(2003,2006)$ and Willis and Willis (Willis 1996; Willis \& Willis 2007). A task has been variously defined as "an activity which requires learners to use language, with emphasis on meaning, to attain an objective" (Bygate, Skehan \& Swain 2001: 11), "a workplan that requires learners to process language pragmatically in order to achieve an outcome that can be evaluated in terms of whether the correct or appropriate propositional content has been conveyed" (Ellis 2003), and "an activity in which people engage to attain an objective, and which involves the meaningful use of language" (Van den Branden, Van Gorp \& Verhelst 2007).

Key features of tasks are summarised by Reinders (2008: 3 ) as follows:

- tasks involve a plan for a learning activity;

- they have a primary focus on making meaning;

- they engage with real-world authentic language use;

- they focus on any or all of the four language skills;

- they engage learners in cognitive skills in order to accomplish them;

- they have a defined communication-based learning outcome.

13 Tasks may be implemented in various ways in the classroom, including approaches which are compatible with the task-based approach adopted in the Common European Reference Framework for Languages (Council of Europe 2001). Thomas and Reinders recommend that TBLT be viewed not as a single method but rather a continuum, "stretching from concerns with the design and adoption of tasks in classroom practice, to the development of task-based language syllabi and curricula" (2010b: 7). Thus a task may constitute anything from one short activity in a language lesson to the foundation for a complete syllabus.

14 Of particular relevance to the theoretical concept of discourse domain and the methodological principles of ESP is the notion of learner engagement with a specific topic in pursuit of the particular goal of improving language competence in a given area. According to Ellis,

task-based teaching calls for the classroom participants to forget where they are and why they are there and to act in the belief that they can learn the language indirectly through communicating in it rather than directly through studying it. (2006: 31)

This requirement speaks both to Douglas's (2004) concern that teaching and testing activities genuinely engage learners in production in their discourse domain, and to Dudley-Evans's (2001) call to involve language learners in discipline-specific activities in the classroom. In this view, then, TBLT involves mimicking real-world activities and methods which can be specific to a particular ESP discipline and which lead to the engagement of learners' discourse domains in order to exploit interlanguage competence, if not drive second language development. In the following section, three examples of university ESP courses with this kind of objective are analysed. 


\section{ESP course design}

16 With the increasing importance of technology in our everyday lives as well as in university teaching contexts (Katz 2008), it is not surprising that many language courses now incorporate elements of Information and Communication Technologies (ICT) in task-based teaching, and even that research specifically focused on TBLT with technology is being carried out (Müller-Hartmann \& Schocker-von Ditfurth 2010; Thomas \& Reinders 2010a). An influential framework for TBLT with technology is outlined in Doughty and Long (2003) and includes the following ten methodological principles:

1. Use tasks, not texts, as the unit of analysis.

2. Promote learning by doing.

3. Elaborate input (do not simplify; do not rely solely on "authentic texts").

4. Provide rich (not impoverished) input.

5. Encourage inductive ("chunk") learning.

6. Focus on form.

7. Provide negative feedback.

8. Respect "learner syllabuses"/developmental processes.

9. Promote cooperative/collaborative learning.

10. Individualise instruction (according to communicative needs, and psycholinguistically).

These principles have been applied to specialist language teaching contexts by Gonzalez-Lloret $(2003,2007)$, showing, for example, how tasks can be designed to support second language students of Spanish literature in understanding and critiquing poetry in Spanish. The author applied general principles of task-based design by first conducting a needs analysis, involving not only a survey of learner preferences but also teacher views and a review of student productions. She then designed a teaching unit, developed learning materials, and finally applied the methodological principles outlined above. The present paper applies the same framework to French university ESP courses in three different domains: business administration, science teaching, and social science research.

\subsection{Teaching context}

Table 1 provides general information about the courses taught at the University of Nice.

Table 1: Overview of graduate ESP courses

\begin{tabular}{|l|l|l|l|}
\hline & Business & Science & Research \\
\hline Course & $\begin{array}{l}\text { English for International } \\
\text { Business }\end{array}$ & English for Science Teachers & $\begin{array}{l}\text { English for Doctoral } \\
\text { Research }\end{array}$ \\
\hline Students & 77 (4 groups) & 13 (1 group) & 13 (1 group) \\
\hline
\end{tabular}




\begin{tabular}{|c|c|c|c|}
\hline Level & $\begin{array}{l}\text { first-year } \quad \text { Master's } \\
\text { (business administration) }\end{array}$ & $\begin{array}{l}\text { first-year Master's (secondary } \\
\text { science teaching) }\end{array}$ & $\begin{array}{l}\text { doctoral studies in } \\
\text { social sciences }\end{array}$ \\
\hline Hours & $\begin{array}{l}2 \times 1 \mathrm{~h} \text { per week over } 10 \\
\text { weeks }=20 \mathrm{~h}\end{array}$ & $\begin{array}{l}10 \times 2 h=20 \text { h over } 10 \text { weeks }= \\
20 \mathrm{~h}\end{array}$ & $\begin{array}{l}4 \times 6 \mathrm{~h} \text { over } 4 \text { weeks }= \\
24 \mathrm{~h}\end{array}$ \\
\hline Teachers & 2 teachers & 1 teacher & 2 teachers \\
\hline Task & $\begin{array}{l}\text { group presentation on } \\
\text { business topic }\end{array}$ & $\begin{array}{l}\text { individual presentation on } \\
\text { science topic }\end{array}$ & $\begin{array}{l}\text { academic } \\
\text { presentation on own } \\
\text { research }\end{array}$ \\
\hline \multirow[t]{3}{*}{ Activities } & $\begin{array}{l}\text { topic research on group } \\
\text { wiki }\end{array}$ & preparation of slides & preparation of slides \\
\hline & preparation of slides & practice and final presentation & $\begin{array}{l}\text { practice and final } \\
\text { presentation }\end{array}$ \\
\hline & $\begin{array}{l}\text { role-play of business } \\
\text { meeting (chair, secretary, } \\
\text { coach) }\end{array}$ & audience feedback & audience feedback \\
\hline \multirow[t]{3}{*}{ Tools } & $\begin{array}{l}\text { class and group wikis } \\
\text { (Wikispaces) }\end{array}$ & class wiki (Google Sites) & $\begin{array}{l}\text { class wiki (Google } \\
\text { Sites) }\end{array}$ \\
\hline & slidecast (Slideshare) & slide embedding (Slideshare) & $\begin{array}{l}\text { slidecast } \\
\text { (Slideshare) }\end{array}$ \\
\hline & & $\begin{array}{l}\text { video podcast } \text { (embedded } \\
\text { video) }\end{array}$ & $\begin{array}{l}\text { video podcast } \\
\text { (embedded video) }\end{array}$ \\
\hline \multirow[t]{2}{*}{ Feedback } & $\begin{array}{l}\text { peer feedback on content } \\
\text { and style }\end{array}$ & $\begin{array}{l}\text { peer feedback on slides and } \\
\text { style }\end{array}$ & $\begin{array}{l}\text { peer feedback on } \\
\text { slides and style }\end{array}$ \\
\hline & $\begin{array}{l}\text { teacher feedback on slides } \\
\text { and oral }\end{array}$ & $\begin{array}{l}\text { teacher feedback on oral } \\
\text { language }\end{array}$ & $\begin{array}{l}\text { teacher feedback on } \\
\text { oral language }\end{array}$ \\
\hline Assessment & $\begin{array}{l}\text { individual presentation } \\
\text { grade }\end{array}$ & individual presentation grade & none \\
\hline $\begin{array}{l}\text { Course } \\
\text { evaluation }\end{array}$ & $\begin{array}{l}\text { anonymous online course } \\
\text { evaluation }\end{array}$ & $\begin{array}{l}\text { anonymous online } \\
\text { questionnaire on ICT for } \\
\text { language learning/teaching }\end{array}$ & $\begin{array}{l}\text { anonymous online } \\
\text { course evaluation }\end{array}$ \\
\hline
\end{tabular}

19 The courses are roughly comparable in terms of class size and length of instruction. With the exception of the intensive doctoral course, they are also fairly typical of Lansad (Langues pour spécialistes d'autres disciplines, or non-language major) courses offered at French universities in general (two hours per week over a 10-week semester). Needs analyses were conducted for each course involving interviews with programme directors, pre-course proficiency tests and learner surveys, and drawing on prior teaching experience where institutional constraints prevented the use of other 
instruments. ESP syllabuses or teaching units were designed as shown in Table 1. The main task involved an oral slide presentation by individuals or groups on a topic in the discipline and following the conventions of each field.

Also shown are the Web 2.0 tools selected for learners to prepare, present, and review course activities, including wikis (or collaborative websites), slidecasts (online slide presentations with audio) and video podcasts (embedded video recordings). The design of each course also took into consideration feedback, assessment and evaluation, in terms of the type of teacher and peer feedback to be provided to learners, assessment for institutional purposes (final grades were required for the two masters courses, but not the doctoral course) and finally post-session evaluation by course participants.

\subsection{Collaborative presentations: English for international business}

Students in this course were enrolled in their first year of a Master's in business administration and specialised in finance and management with a curriculum which placed emphasis on group collaboration in project work, and the use of technology for teaching and learning. The first year programme included a training placement in international banks and businesses which frequently required spoken English skills, including presentation skills. A teaching unit was accordingly designed to provide opportunities for collaboration on oral presentations with learning materials to be selected by learners to support a group presentation task. Seven of the ten methodological principles developed by Doughty and Long (2003) were then chosen for the course and applied as shown in Table 2.

Table 2: Methodological principles in the English for business course

\begin{tabular}{|c|c|c|c|c|c|}
\hline \multicolumn{2}{|c|}{$\begin{array}{l}\text { Methodological } \\
\text { principles }\end{array}$} & Activities & Teacher & Learners & Tools \\
\hline 1 & $\begin{array}{l}\text { Use tasks, not texts, as } \\
\text { the unit of analysis. }\end{array}$ & $\begin{array}{l}\text { business } \\
\text { presentation }\end{array}$ & & & \\
\hline 2 & $\begin{array}{l}\text { Promote learning by } \\
\text { doing. }\end{array}$ & $\begin{array}{l}\text { research, } \\
\text { analyse and } \\
\text { present; role- } \\
\text { play business } \\
\text { meeting }\end{array}$ & & $\begin{array}{l}\text { select and } \\
\text { analyse source } \\
\text { materials, } \\
\text { prepare slides, } \\
\text { give group } \\
\text { presentation, } \\
\text { role-play } \\
\text { business meeting }\end{array}$ & $\begin{array}{l}\text { group wiki } \\
\text { (Wikispaces) }\end{array}$ \\
\hline 3 & $\begin{array}{l}\text { Elaborate input (do not } \\
\text { simplify; do not rely } \\
\text { solely on "authentic } \\
\text { texts") }\end{array}$ & $\begin{array}{l}\text { select } \\
\text { resources to } \\
\text { work on with } \\
\text { teacher }\end{array}$ & \begin{tabular}{|ll} 
classroom & \\
analysis & of \\
learner- & \\
selected & audio \\
and & video \\
resources &
\end{tabular} & & \\
\hline
\end{tabular}




\begin{tabular}{|c|c|c|c|c|c|}
\hline 4 & $\begin{array}{l}\text { Provide rich (not } \\
\text { impoverished) input }\end{array}$ & $\begin{array}{l}\text { find } \quad \text { own } \\
\text { audio, video } \\
\text { resources }\end{array}$ & & $\begin{array}{l}\text { select own audio } \\
\text { and } \\
\text { resources }\end{array}$ & $\begin{array}{l}\text { group wiki } \\
\text { (Wikispaces) }\end{array}$ \\
\hline 7 & $\begin{array}{l}\text { Provide } \quad \text { negative } \\
\text { feedback }\end{array}$ & $\begin{array}{l}\text { immediate oral } \\
\text { feedback to } \\
\text { group; } \\
\text { individual } \\
\text { written } \\
\text { feedback }\end{array}$ & $\begin{array}{l}\text { written } \\
\text { feedback on } \\
\text { slides, } \\
\text { individual } \\
\text { written } \\
\text { feedback on } \\
\text { audio recording } \\
\text { of presentation }\end{array}$ & $\begin{array}{l}\text { review written } \\
\text { feedback outside } \\
\text { class with access } \\
\text { tor original } \\
\text { materials (slides, } \\
\text { audio recording) }\end{array}$ & $\begin{array}{l}\text { audio recording } \\
\text { of presentation } \\
\text { synchronised } \\
\text { with slides } \\
\text { online } \\
\text { (slidecast); } \\
\text { group wiki } \\
\text { (wikispaces) }\end{array}$ \\
\hline 9 & $\begin{array}{l}\text { Promote cooperative/ } \\
\text { collabora-tive learning }\end{array}$ & $\begin{array}{l}\text { group } \\
\text { presentation, } \\
\text { peer feedback }\end{array}$ & & $\begin{array}{l}\text { group } \\
\text { collaboration to } \\
\text { prepare and } \\
\text { deliver } \\
\text { presentation } \\
\text { with slides; } \\
\text { audience role- } \\
\text { play (chair, } \\
\text { secretary, coach) }\end{array}$ & $\begin{array}{l}\text { group wiki } \\
\text { (Wikispaces) }\end{array}$ \\
\hline 10 & $\begin{array}{l}\text { Individualise } \\
\text { instruction (according } \\
\text { to communicative } \\
\text { needs, and } \\
\text { psycholinguistically) }\end{array}$ & $\begin{array}{l}\text { individual } \\
\text { feedback, } \\
\text { choice of topic }\end{array}$ & & $\begin{array}{l}\text { individual } \\
\text { written feedback }\end{array}$ & $\begin{array}{l}\text { group wiki } \\
\text { (Wikispaces) }\end{array}$ \\
\hline
\end{tabular}

In this course, students gave presentations with slides on a business topic of their choice in groups of four to six students. Students researched presentation topics using group wikis with one teacher and gave their group presentation in the other teacher's class. The slides and audio recordings, plus peer and teacher feedback were posted to the class wiki. (See Appendix A for more details).

The application of the methodological principles (MP) used to design and implement the course is analysed in the three sections below.

\subsubsection{Tasks, learning by doing, and collaboration}

Course design focused on tasks, learning by doing (MP2) and cooperative/collaborative learning. The course was designed around a final task - a group slide presentation to the class - rather than a selection of texts (print or audio-visual documents). The task required students to research a business topic in groups, imitating real-world tasks where colleagues share information and prepare presentations together. Students prepared for the task by using the online tools of a collaborative website to share resources and develop ideas for their presentation, again in ways similar to collaboration in the workplace. The actual group presentation was a cooperative task where each student intervened at a pre-determined point, and the other students in the class also participated in a collaborative effort to approximate a business 
environment where English is the lingua franca and roles such as chair and secretary are common, and coaching may occur.

The task was therefore authentic in design, since it replicated business presentations students may need to give in their future professional lives, and also in its implementation, since the task context also imitated business contexts. The activities leading up to the final task promoted learning by doing, since the students selected and analysed source materials, prepared slides and practiced presenting in ways similar to practices in the business community. The students also worked cooperatively or collaboratively, since each group organised tasks and assigned responsibilities to group members independently. The present study did not investigate groups' cooperative or collaborative processes.

A further aspect of collaboration can be seen in peer feedback to individual speakers from the class. In this way factors beyond English fluency and accuracy were addressed, and some responsibility for feedback was devolved from teachers to learners.

\subsubsection{Rich input and elaboration}

This business course also sought to respect Doughty and Long's principles regarding input: elaborate input (do not simplify; do not rely solely on "authentic texts") and provide rich (not impoverished) input. These principles address two aspects of the language input provided to learners. On the one hand, the language which they are exposed to should not be simplified in terms of vocabulary, grammar, or content as is sometimes the case in textbooks for second language learners, because language acquisition requires exposure to rich samples of the language which exhibit its complex features. On the other hand, mere exposure to authentic texts will not support language acquisition if learners are unable to make sense of them. Teachers must be able to "elaborate" on samples of rich input, by designing activities to support comprehension and discussion, by paraphrasing, expanding, and explaining expressions and concepts, and by providing feedback on learners' attempts to incorporate new language features into their own interlanguage production.

This course required learners to find authentic sources of input for the task. Teachers then supported the learners in discussion sessions where these resources were analysed and debated, allowing learners to develop listening and reading skills, and learn concepts and expressions which would be reused during their group presentations.

\subsubsection{Negative feedback and individualised instruction}

29 Finally, the course also took into account MP7, provide negative feedback, and MP10, individualise instruction, by providing individual written feedback on slides and oral presentations which could be accessed online, together with learners' productions, outside class. In the evaluations carried out at the end of the course, many students commented favourably on this system for providing feedback, highlighting the importance of being able to listen to themselves and identify their own errors.

A voluntary, anonymous online post-course questionnaire was returned by 23 of the 77 students who completed the course (Appendix A). The majority of responses (14/23) were positive: respondents most valued the PowerPoint presentation activity (1.96) but 
disagreed that their English was better after the course (3.30), or that group work helped them learn (3.22).

31 Seven respondents found accessing their group slidecasts with teacher feedback a novel and helpful way to evaluate their speaking, though one noted "It would have been interesting to talk about that with you [the teacher] in class for each student. But I think it is due to the timing." It is often the case that feedback on student performance in ESP and other language courses comes too late for reflection and improvement.

Negative feedback included calls for a more "professional focus" suggesting that some learners were not able or willing to "act in the belief that they can learn the language indirectly through communicating in it rather than directly through studying it" (Ellis 2006: 89). Nor did these learners seem to accept responsibility for the development of their own discourse domains in business, or for interlanguage development in general, expecting the teacher to provide specialised vocabulary and texts rather than seeking out their own resources to fit these needs.

\subsection{Individual presentations: English for science teachers}

The second course in this study was for students in their first year of a Master's programme for secondary school science teachers (physics and chemistry). A general reform of French teaching training has recently integrated teacher training institutes into mainstream universities and this ESP course for pre-service science teachers was an innovation in the new programme. While these students had no clearly identifiable need to develop English proficiency for their future teaching positions, they could conceivably exploit the large number of online pedagogical resources in English in their classrooms, as well as access scientific research in English, as they had during their previous studies. The course therefore focused on activating passive knowledge of English and developing oral skills, in keeping with the course director's recommendations, the teacher's previous experience with ESP students, and also following pre-test findings which showed better listening and reading proficiency than speaking and writing skills.

A teaching unit was designed around individual presentations with slides on a science topic, either a research-oriented presentation or a short lecture or demonstration suitable for a high school science class (more details of the course can be found in Appendix B).

The methodological principles underpinning this course design and implementation are shown in Table 3.

Table 3: Methodological principles in the English for science teachers course

\begin{tabular}{|l|l|l|l|l|l|}
\hline \multicolumn{2}{|l|}{$\begin{array}{l}\text { Methodological } \\
\text { principles }\end{array}$} & Activities & Teacher & Learners & Tools \\
\hline 1 & $\begin{array}{l}\text { Use tasks, not texts, as } \\
\text { the unit of analysis. }\end{array}$ & $\begin{array}{l}\text { science } \\
\text { presentation }\end{array}$ & & & \\
\hline
\end{tabular}




\begin{tabular}{|c|c|c|c|c|c|}
\hline 2 & $\begin{array}{l}\text { Promote learning by } \\
\text { doing. }\end{array}$ & $\begin{array}{l}\text { practice and } \\
\text { final } \\
\text { presentation }\end{array}$ & & $\begin{array}{lr}\text { select } & \text { source } \\
\text { materials, } & \text { prepare } \\
\text { slides, r give } \\
\text { presentation, } \\
\text { provide feedback } \\
\text { to others }\end{array}$ & $\begin{array}{l}\text { class wiki } \\
\text { (Google site) }\end{array}$ \\
\hline 4 & $\begin{array}{l}\text { Provide rich (not } \\
\text { impoverished) input }\end{array}$ & $\begin{array}{l}\text { select } \\
\text { resources to } \\
\text { support } \\
\text { presentation }\end{array}$ & & $\begin{array}{ll}\text { select own } & \text { audio } \\
\text { and } & \text { video } \\
\text { resources } & \end{array}$ & $\begin{array}{l}\text { class wiki } \\
\text { (Google site) }\end{array}$ \\
\hline 6 & Focus on form & & $\begin{array}{l}\text { provide written } \\
\text { feedback on } \\
\text { each } \\
\text { presentation }\end{array}$ & $\begin{array}{lr}\text { review } & \text { written } \\
\text { feedback } & \text { outside } \\
\text { class with } & \text { access to } \\
\text { original } & \text { materials } \\
\text { (slides, video) }\end{array}$ & $\begin{array}{l}\text { video } \\
\text { recording of } \\
\text { presentations } \\
\text { embedded on } \\
\text { group wiki }\end{array}$ \\
\hline 7 & $\begin{array}{l}\text { Provide } \quad \text { negative } \\
\text { feedback }\end{array}$ & $\begin{array}{l}\text { immediate } \\
\text { oral feedback } \\
\text { to group; } \\
\text { written } \\
\text { feedback }\end{array}$ & \begin{tabular}{|l|} 
written \\
feedback on \\
slides, \\
individual \\
written \\
feedback on \\
audio recording \\
of presentation
\end{tabular} & & \\
\hline 8 & $\begin{array}{l}\text { Respect "learner } \\
\text { syllabuses"/ } \\
\text { developmental } \\
\text { processes }\end{array}$ & $\begin{array}{l}\text { written } \\
\text { feedback on } \\
\text { presentation }\end{array}$ & $\begin{array}{lr}\text { feedback } & \text { based } \\
\text { on } & \text { learner } \\
\text { errors } & \text { in } \\
\text { meaningful } & \\
\text { context } & \end{array}$ & $\begin{array}{lr}\text { feedback } & \text { on } \\
\text { language } & \text { in } \\
\text { context } & \text { of } \\
\text { presentation; } & \\
\text { reflection } & \text { on } \\
\text { feedback before } \\
\text { revised } \\
\text { presentation }\end{array}$ & $\begin{array}{l}\text { class wiki with } \\
\text { embedded } \\
\text { video }\end{array}$ \\
\hline 9 & $\begin{array}{l}\text { Promote cooperative/ } \\
\text { collaborative learning }\end{array}$ & peer feedback & & $\begin{array}{l}\text { provide feedback } \\
\text { on communication, } \\
\text { slides and content }\end{array}$ & $\begin{array}{l}\text { paper } \\
\text { evaluation } \\
\text { grids; class } \\
\text { wiki (Google } \\
\text { site) }\end{array}$ \\
\hline 10 & $\begin{array}{l}\text { Individualise } \\
\text { instruction (according } \\
\text { to communicative } \\
\text { needs, and } \\
\text { psycholinguistically) }\end{array}$ & \begin{tabular}{|l|} 
individual \\
feedback, \\
choice of \\
topic
\end{tabular} & & $\begin{array}{l}\text { individual written } \\
\text { feedback }\end{array}$ & $\begin{array}{l}\text { class wiki } \\
\text { (Google site) }\end{array}$ \\
\hline
\end{tabular}

The implementation of these principles is shown in the three following sections on tasks and learning by doing, rich input and collaboration, and form-focused feedback and individualised instruction. 


\subsubsection{Tasks and learning by doing}

the business course, because the participants had no well-defined purpose for learning English and no likely future context for use. On the other hand, as pre-service teachers, these students did need to learn to participate in a certain number of clear-cut speech events in the very specific discourse context of the French secondary school classroom, thus the presentation task selected for the course did have some real-world relevance. Eleven of the fourteen students chose a presentation type suited to secondary school learners, suggesting that they recognised the quasi-authentic character of this task. The principle of learning by doing was implemented by having learners seek out English resources for content or linguistic input on their topics, then giving a practice presentation, reviewing feedback, and presenting a second time.

\subsubsection{Rich input and collaboration}

Learners were encouraged to incorporate English expressions taken from authentic resources related to their topics, and even to include excerpts from these audio-visual resources in their presentations. Some students consulted British and American science education websites and replicated the demonstrations they found there in class, while others showed excerpts from science news reports or educational resources in their research presentations. While each student was responsible for his or her own presentation, each was also required to provide feedback on classmates' presentations, introducing a collaborative element to coursework. After the first presentation, students summarised peer feedback concerning delivery, content, slides, and overall effect on their wiki page, and wrote a conclusion regarding changes to be made for the second presentation.

\subsubsection{Focus on form and individualised instruction}

The feedback system selected for this course allowed for individualised instruction in a number of ways. Learners selected both the topic and the type of presentation they wished to give, and had freedom to choose their own resources. They also received the negative feedback which permits efficient language learning: for both practice and final presentations, the teacher gave written feedback on each learner's wiki page, just below the embedded video recording of the presentation. This feedback conformed to two different methodological principles: focus on form (or focused grammar feedback in a context of meaningful communication) and respect of learner syllabuses or internal IL grammars. Unlike the business presentations, where learners selected rather general topics which were unlikely to engage any developing discourse domain, the science presentations directly involved students' content knowledge in a context which closely approximated real-life situations. Each student's presentation therefore represented a meaningful context for ESP use, and feedback on form (pronunciation, vocabulary, grammar) thus had a good chance of being relevant and easily interpretable. In addition, since each student presented only simple slides without additional notes, the presentations closely approximated their current level of spoken English. Thus the corrective feedback offered was delivered at each student's level of development, again increasing its potential effectiveness.

ASp, 63 | 2013 

of technology for teaching and learning languages (and thus not directly soliciting an evaluation of this particular course). The majority of respondents attended all or most class meetings; half claimed to have made efforts to learn. Regarding their views of technology for language learning, most of this group valued the affordances of the internet and Web 2.0 tools to permit learners to find resources, to allow teachers to provide feedback, and for sharing learner productions, all of which were exploited in this course.

\subsection{Conference presentations: English for doctoral research}

41 The third course analysed in this paper was an intensive course for doctoral students in the humanities faculty, and included students in sociology, psychology, geography, comparative literature, communication, and linguistics. This course might be seen as closer to a CLIL (content and language integrated learning) class than the others since, as academics in the social sciences (geography and applied linguistics), the teachers were members of the discourse community or community of practice in question. Unlike the other courses, the English for doctoral research course was not a new course. Thus information for the needs analysis for this course was already available from teaching experience and participant course evaluation of the earlier editions, with the course objective of providing academic coaching to help doctoral students present and publish their research in English. Thirteen participants were selected from a pool of seventeen on the basis of a pre-test of their language proficiency, including an interview to evaluate oral skills but also gauge students' professional projects. A precourse questionnaire (see Appendix C) was also used to verify learners' perceived abilities and needs; this revealed lacunae in productive skills, particularly speaking, as was the case in previous years.

A course was designed around the central task of giving a conference presentation on students' own research, with additional tasks of writing an academic CV and a scientific abstract. The following analysis focuses on the presentation task. Students made a short preliminary slide presentation and prepared an oral recording which they synchronised online and shared on the class wiki. After feedback from the class and one teacher, they then gave full presentations in the second teacher's class, which was organised to imitate an academic conference session. These presentations were filmed and streamed on the class wiki, and written feedback was provided by class members on content, slides, and communication and by the first teacher on language use. The tasks and tools are therefore comparable to those used in both the business and science teachers' courses.

As in the previous courses, the methodological principles involved include MP1 (tasks, not texts); MP 2 (learning by doing) and MP9 (collaboration); and MP6 (focus on form), MP7 (negative feedback), MP8 (learner syllabus) and MP10 (individualise instruction). These are shown in Table 4.

Table 4: Methodological principles in the English for doctoral research course

\begin{tabular}{|l|l|l|l|l|}
\hline $\begin{array}{l}\text { Methodological } \\
\text { principles }\end{array}$ & Activities & Teacher & Learners & Tools \\
\hline
\end{tabular}




\begin{tabular}{|c|c|c|c|c|}
\hline $\begin{array}{l}\text { Use tasks, not texts, as } \\
\text { the unit of analysis. }\end{array}$ & $\begin{array}{l}\text { conference } \\
\text { presentation, CV, } \\
\text { research abstract }\end{array}$ & & & \\
\hline $\begin{array}{l}\text { Promote learning by } \\
\text { doing. }\end{array}$ & $\begin{array}{l}\text { making slides, } \\
\text { recording practice } \\
\text { presentation, } \\
\text { giving final } \\
\text { presentation }\end{array}$ & & $\begin{array}{l}\text { give presentation, } \\
\text { participate in } \\
\text { conference } \\
\text { session, provide } \\
\text { feedback }\end{array}$ & $\begin{array}{l}\text { slides, class } \\
\text { wiki } \\
\text { (Google } \\
\text { site) }\end{array}$ \\
\hline Focus on form & & $\begin{array}{l}\text { oral and written } \\
\text { feedback on } \\
\text { audio and video } \\
\text { recorded } \\
\text { presentations }\end{array}$ & $\begin{array}{lr}\text { review } & \text { feedback } \\
\text { for } & \text { revised } \\
\text { presentation }\end{array}$ & \\
\hline $\begin{array}{l}\text { Provide } \quad \text { negative } \\
\text { feedback }\end{array}$ & & $\begin{array}{l}\text { feedback } \quad \text { on } \\
\text { speaking, writing }\end{array}$ & $\begin{array}{lr}\text { review } & \text { feedback } \\
\text { for } & \text { revised } \\
\text { presentation }\end{array}$ & $\begin{array}{l}\text { class wiki } \\
\text { (Google } \\
\text { site) }\end{array}$ \\
\hline $\begin{array}{l}\text { Respect "learner } \\
\text { syllabuses"/ } \\
\text { developmental processes }\end{array}$ & & focused feedback & & $\begin{array}{l}\text { class wiki } \\
\text { (Google } \\
\text { site) }\end{array}$ \\
\hline $\begin{array}{l}\text { Promote cooperative/ } \\
\text { collaborative learning }\end{array}$ & $\begin{array}{l}\text { peer feedback on } \\
\text { presentations, } \\
\text { group activities }\end{array}$ & & $\begin{array}{l}\text { written feedback } \\
\text { on presentations, } \\
\text { group activities in } \\
\text { class }\end{array}$ & $\begin{array}{l}\text { slidecast, } \\
\text { video } \\
\text { podcast, } \\
\text { class wiki } \\
\text { (Google } \\
\text { site) }\end{array}$ \\
\hline $\begin{array}{l}\text { Individualise instruction } \\
\text { (according to } \\
\text { communicative needs, } \\
\text { and psycholinguistically) }\end{array}$ & & $\begin{array}{lr}\text { individual } & \\
\text { support } & \text { for } \\
\text { preparation } & \text { of } \\
\text { presentation } & \end{array}$ & $\begin{array}{l}\text { exploit own } \\
\text { resources, present } \\
\text { own research }\end{array}$ & $\begin{array}{l}\text { class wiki } \\
\text { (Google } \\
\text { site) }\end{array}$ \\
\hline
\end{tabular}

\subsubsection{Tasks}

44 As mentioned above, the presentation task in this course comes very close to an authentic task. Indeed, three course participants were already planning actual conference presentations and used the course to practice. A student who was not presenting was assigned the role of session chair, charged with introducing the presenter and keeping time, while others asked questions and made notes for feedback on communication. The only differences between this classroom task and an actual conference presentation concerns the presentation length, at ten minutes somewhat shorter than a usual conference talk, and the audience, which was predominantly nonspecialist, since the teachers were obviously specialists in only one academic discipline, and the students came from different fields. 


\subsubsection{Learning by doing and cooperation} teachers' course, this course also helped learners to learn by doing. Class activities, however, created more opportunities for group work in this intensive course and allowed learners to practice in small groups, help each other with language and other issues (communication), and give and receive feedback in English (see Appendix C for a sample of group activities).

\subsubsection{Individualised instruction and feedback} and respect learner syllabuses, as well as provide negative feedback which focused on form. The entire course was structured around participants' own research interests, allowing them to focus on presenting their field and their research questions to classmates who shared some of their academic and social background. Feedback was given individually on language which had been produced with a clear focus on conveying meaning. Learners could also access recordings of their performances, allowing them the opportunity to hear errors and thus helping them to understand and accept feedback. Perhaps more than in the other courses, then, these learners were likely to be engaging in discourse domain talk, to the extent that they were invoking extensive, important, and current knowledge in relation to their doctoral research.

of the thirteen course participants completed an anonymous online course evaluation questionnaire during the final class meeting. Respondents strongly agreed that the course content, level, and activities suited their needs, and that after the course they felt more confident using English in their research (4.56 on each statement). The strongest approval was for the statement "I enjoyed working with the other students and learned from them" (4.89), and respondents also felt their English had improved (4.44), particularly in terms of pronunciation (4.56). Other views were more nuanced: approval of the slide presentation activity (4.11) and watching the video of the presentation (3.89).

In the open-ended section of the doctoral research questionnaire, the most frequent comment concerned respondents' appreciation of group work and collaboration with students in other disciplines. They also valued the opportunity to interact spontaneously in the oral language, with feedback on pronunciation rather than grammar, and also found the teachers' input and engagement motivating, particularly in terms of analysing presentations. Negative comments were rare, generally concerning lack of time; like the business students, several wanted more class hours.

\section{Discussion}

The foregoing analysis of curriculum design in the three graduate ESP courses has highlighted a certain number of methodological principles which bear further examination. Questions concerning the design and implementation of tasks (MP1, MP2), teacher feedback and focus on form (MP6, MP7), learner cooperation and collaboration (MP9), and learner syllabuses (MP8) are addressed in turn. 


\subsection{Designing tasks and performing tasks}

The first issue concerns task authenticity and relevance. What do learners perceive as a worthwhile task, how are they motivated to engage with tasks, and how does this affect their perception of learning? The presentation tasks defined for the three different groups of learners investigated in this paper varied in their degree of authenticity in terms of real-world relevance, yet learners in all groups engaged with course tasks, and had generally positive views of these activities. The doctoral students displayed perhaps the strongest approval of proposed tasks, and this may reflect the greater authenticity of the conference presentation task but also their greater engagement with their presentation topics which were likely to constitute discourse domain topics. The business students also gave a high approval rating to their PowerPoint presentation task, but seemed less convinced that this task helped them to improve their English. It may be that the presentation topics selected by the students were less clearly domain topics for these learners: as less advanced graduate students, they had perhaps less content knowledge in their field, or they chose not to tackle the most technical aspects of the topics in their group presentations. They may also have considered that the non-specialist teachers did not constitute an appropriate audience for domain talk. In contrast, the pre-service science teachers, with no real need to improve their English presentation skills did nonetheless engage with the science teaching content. In several cases, students went beyond minimal task requirements to bring props for a classroom demonstration and extensively revise talks for the second presentation, although course feedback suggested the class was not a priority for them.

\subsection{Teacher feedback and focus on form}

51 The present study did not seek to measure proficiency gains but the data collected do provide insights into learner perceptions of teacher feedback on their language production. In the business course, feedback was provided after presentations towards the end of the course, with no opportunity for learners to reflect and integrate information. The students who responded to the final course evaluation were generally pleased to be able to access their feedback together with the presentation recording, but it is likely that not all students took advantage of this opportunity. In addition, the business students were the only group to question the task-based course design, with several post-course comments calling for the teacher to provide more vocabulary, translation equivalents, or, in one case, grammar exercises. Given the institutional constraints on conducting a needs analysis with this large and heterogeneous group of learners, it was more difficult to convince learners of the advantages of this type of course and persuade them to "buy into" task-related activities, and more particularly since feedback came at the end of the task cycle.

52 The science teachers' and doctoral researchers' course design sought to address these issues in two ways. Both groups took a pre-course proficiency test as part of the needs analysis and were found to command specialised vocabulary in their fields, but to have difficulties with pronunciation (word stress and intonation), as well as general discourse conventions governing respectively pedagogical or academic talks. Thus teacher feedback concentrated on those areas when helping students to focus on form in their presentations. In addition, the fact that feedback occurred midway through the course in the case of the science teachers, and from the first class session for the 
doctoral researchers, allowed students to gauge their level of English and participate in explicit language-oriented discussion while there was still time to reflect and adapt. This course design therefore made it easier for learners to accept the task-based orientation as a serious alternative to the grammar-based instruction they were used to. Indeed, in post-course comments, the doctoral students appreciated focused feedback on their presentations, particularly regarding pronunciation, as opposed to studying grammar "again," as one put it.

\subsection{Learner collaboration and group work}

The courses analysed in this paper also throw up interesting questions about collaboration and group work. Of the three types of students in the different courses examined, arguably the business students had the greatest need for collaborative skills, and project work featured prominently in their Master's programme outside the English classroom. However, some of these students expressed a dislike of group work in English, citing problems of proficiency disparities, and in informal discussion, expressing fears about unequal workload and grades as well as reticences regarding unfamiliar classmates whom they only met in English classes. In the science course, the enrolment was much lower, and as students took all classes in their programme together, they were more comfortable working with one another. The course with perhaps the least collaborative habits and needs outside the English class was the doctoral research course, where students had few if any other required courses and were each pursuing individual research goals in different laboratories or independently. Yet this was the course where students most valued group work, which they found motivating and supportive of learning. Clearly, local contexts for collaboration are important and it is difficult to predict learner needs and preferences regarding working together on tasks.

\subsection{Learner syllabuses and interlanguage development}

If tasks, feedback and collaboration are central to language teaching and learning, it is because second language theory suggests that effective contributions in these areas from both teacher and learners can increase the efficiency of language learning processes and promote the development of each learner's interlanguage or internal syllabus. Using texts instead of tasks risks providing input too simple or too advanced for learning to occur; feedback on language errors on features too far beyond learners' current IL competence is likely to be ineffective (and demotivating); classroom interaction which is restricted to short teacher-learner exchanges with one learner at a time does not allow learners enough opportunities to hear and use the target language. Discourse domain theory further claims that tasks and interaction on a particular domain topic may influence acquisition processes. It is interesting that those students who were likely to have the most developed discourse domains for their presentation topics, the doctoral researchers, were those who thought their English skills were better and were more confident using English at the end of the course. 


\section{Conclusion} contexts more often involve teachers who are content experts rather than language specialists. As Dalton-Puffer points out, the less authentic CLIL classroom setting offers a safe framework for learners to develop content knowledge and language skills, benefiting from their "cultural familiarity with the domain of use and its rules" (2011: 195), that is, the classroom setting. Other researchers also downplay the importance of specialised interlocutors in ESP courses: Hyland sees benefits for learners in talking about their specialised fields to non-specialist audiences:

By making contact with those outside their field, students may more easily come to see that communication does not entail adherence to a set of universal rules but involves making rational choices based on the ways texts work in specific contexts. (2002: 393)

The question of learner autonomy remains: in a task-based approach founded on a discourse domain view of language use, learners must take some responsibility for their own learning in terms of finding resources, participating in activities, and reflecting on performance. The discussion of the different ESP courses in this paper has shown a complex interplay of factors affecting motivation, collaboration, and reflection with respect to the different tasks in each course. It is clear that effective university ESP tasks cannot be generic, one-size-fits-all. While recent moves towards task-based teaching and testing in university Lansad language courses are to be applauded, it is unfortunate that examination tasks do not seek to meet the main criteria of TBLT and are generally not specific to learners' disciplines. If the TBLT implementation proposed in this paper is to gain greater currency in French universities, institutional settings need to be flexible enough to accommodate courses which more closely reflect a serious analysis of learners' needs and objectives. 

Second Language Acquisition (SLA) and ESP? Concerning the relative importance accorded to systematicity and variation in second language research, this paper adopts a variationist stance by taking a discourse domain approach to second language use. It is argued that this theory is particularly relevant to ESP concerns since it provides theoretical underpinning for observations regarding language use in particular contexts. Discourse domain theory suggests that advanced learners with specific content knowledge of a field which is currently important and relevant to them need to engage those domains in their second language practice. Here the notion of "advanced" learner refers, of course, to content (disciplinary) expertise or domain development as opposed to linguistic or cultural knowledge, or to communicative, or interactional competence in the second language. It speaks directly to the French higher education term Lansad, which focuses on "specialists of other disciplines" in opposition to language specialists, or students of the literature and language of the target culture, where an advanced learner has amassed substantial linguistic and cultural knowledge (generally in preparation for teaching).

From a discourse domain perspective, as graduate students, and thus incipient "experts" in well-defined fields, both language/literature specialists and Lansad students develop and use language skills in a similar manner in the process of becoming members of separate but comparable communities of practice. With respect to ESP, English Master's students preparing for national competitive teaching exams and undergoing training in secondary school classes develop a discourse domain for English teaching involving content expertise in the language and culture of Englishspeaking countries as well as the national teaching programmes, and become members of a community of practice of French high school teachers of English. Similarly, doctoral researchers in social science develop discourse domains for their areas of research allowing them to participate in discourse events and academic communities in these fields. In this respect, discourse domain theory offers a general framework within which each specialisation can be addressed.

Given this theoretical coherence, the present paper further suggests that different areas of specialisation can therefore be usefully tackled from the same teaching perspective, and proposes a task-based approach. TBLT starts from a needs analysis of each learner group which includes typical activities, contexts and discourse events, and then provides a framework for designing and implementing materials and tasks which are likely to promote the development of second language competence to meet the learners' particular needs. This paper has noted a number of examples of TBLT courses in higher education: the three French university Lansad courses which were analysed in detail, and the Spanish literature course outlined in González-Lloret (2007). It seems reasonable to conclude that TBLT offers both the flexibility and the rigour to suit a wide range of teaching contexts and learner needs.

Is there, then, a need for a new approach to language learning and teaching that is tailored to English for Specific Purposes, perhaps even English for Academic or Research Purposes? I would argue yes and no: it is clear that the need for ESP courses is well justified and that generic English courses cannot meet learners' needs. It is important that the design and implementation of such courses be based on the best available information about second language acquisition and pedagogy. But we already have theories of language acquisition and use, as well as language teaching, which can 
inform effective ESP teaching and learning. English is one language among many, and all are learned via universal processes; similarly, the specific purposes of our courses are all amenable to task-based approaches. Perhaps the next step in promoting effective ESP learning and teaching in higher education contexts lies in the definition of particular domains and the systematic application of principles of task-based learning and teaching to each. In this way, teaching can respect the specificity of ESP contexts in the design of appropriate language courses based on authentic tasks which motivate learners and promote effective language learning.

\section{BIBLIOGRAPHY}

Bertin, Jean-Claude, Patrick Gravé \& Jean-Pierre Narcy-Combes. 2010. Second Language Distance Learning and Teaching: Theoretical perspectives and didactic ergonomics. Hershey, PA: IGI Global.

Bygate, Martin, Peter Skehan \& Merrill Swain (eds). 2001. Researching Pedagogical Tasks: Second language learning, teaching, and assessment. London: Pearson.

Chang, Yu Fang. 2008. "The influence of content knowledge on NNS-NNS conversations". JALT Journal 30/2, 153-171.

Council of Europe. 2001. "Common European Framework of Reference for Languages: Learning, Teaching, Assessment”. Retrieved in October 2012. <http://www.coe.int/t/dg4/ linguistic/ Source/Framework_EN.pdf>.

Dalton-Puffer, Christiane. 2011. "Content-and-Language Integrated Learning: From Practice to Principles?”. Annual Review of Applied Linguistics 31, 182-204.

Doughty, Catherine \& Michael Long. 2003. "Optimal psycholinguistic environments for distance foreign language learning”. Language Learning \& Technology 7, 50-80.

Douglas, Dan. 2004. "Discourse domains: The cognitive context of speaking”. In Boxer, D. \& A. Cohen (eds.), Studying Speaking to Inform Second Language Learning. Clevedon, UK: Multilingual Matters, 25-47.

Douglas, Dan \& Larry Selinker. 1985. "Principles for language tests within the 'discourse domains' theory of interlanguage". Language Testing 2/2: 205-226.

Dudley-Evans, Tony. 2001. "English for specific purposes”. In Carter, R \& D Nunan (eds.), The Cambridge Guide to Teaching English to Speakers of Other Languages. Cambridge: Cambridge University Press, 131-136.

Ellis, Rod. 2003. Task-Based Language Learning and Teaching. Oxford: Oxford University Press.

Ellis, Rod. 2006. "The methodology of task-based teaching." Asian EFL Journal 8/3: 19-45. Retrieved in October 2012. <http://www.asian-efl-journal.com/September_2006_EBook_editions.pdf>.

Gonzalez-Lloret, Marta. 2003. "Designing task-based call to promote interaction: En Busca de Esmeraldas". Language Learning \& Technology, 7(1), 86-104. Retrieved in October 2112. <http:// llt.msu.edu/vol7num1/gonzalez/>. 
González-Lloret, Marta. 2007. "Implementing task-based language teaching on the web". In Van den Branden, K., M. Verhelst \& K. Van Gorp (eds.), Task-based Language Education. Cambridge: Cambridge Scholars Press, 265-284.

Guichon, Nicholas \& Viorica Nicolaev. 2011. "Influence de certaines caractéristiques des tâches d'apprentissage sur la production orale en L2". In Nissen, E., F. Poyet \& T. Soubrié. (eds.). Interagir et apprendre en ligne. Grenoble: Ellug, 61-76.

Hyland, Kenneth. 2002. “Specificity revisited: how far should we go now?”. English for Specific Purposes 21, 385-395.

Katz, Richard (ed.). 2008. The Tower and the Cloud: Higher education in the age of cloud computing. Boulder, CO: EDUCAUSE.

Larsen-Freeman, Diane \& Michael Long. 1991. An Introduction to Second Language Acquisition Research. London: Longman.

Long, Michael. 1989. “Task, group, and task-group interaction”. University of Hawai'i Working papers in English as a Second Language 8/2, 1-26.

Long, Michael. 1998. “SLA: Breaking the siege”. University of Hawai'i Working Papers in ESL 17, 79-129.

Mitchell, Rosamund, \& Florence Myles. 2002. Second Language Learning Theories. London: Hodder. Müller-Hartmann, Andreas \& Marita Schocker-von Ditfurth. 2010. "Research on the use of technology in task-based language teaching”. In Thomas, M. \& H. Reinders (eds.), Task-based Language Teaching and Technology. New York: Continuum, xx.

Reinders, Hayo. 2008. "The effects of implicit and explicit instructions on acquisition of two English grammatical structures”. Korean Journal of Applied Linguistics 24/1, 1-17.

Samuda, Virginia \& Martin Bygate. 2008. Tasks in Second Language Learning. London: Palgrave.

Selinker, Larry. 1972. "Interlanguage”. IRAL 10, 209-31.

Selinker, Larry \& Dan Douglas. 1985. "Wrestling with context in interlanguage theory". Applied Linguistics 6/2, 190-204.

Skehan, Peter. 2003a. “Task-based instruction”. Language Teaching 36, 1-14.

Skehan, Peter. 2003b. "Focus on form, tasks, and technology". Computer Assisted Language Learning 16/5, 391-411.

Tarone, Elaine. 2000. "Still wrestling with 'context' in interlanguage theory". Annual Review of Applied Linguistics 20, 182-198.

Tarone, Elaine. 2007. "Sociolinguistic approaches to second language acquisition research 1997-2007”. Modern Language Journal 91, 837-48.

Thomas, Michael \& Hayo Reinders (eds.) 2010a. Task-Based Language Teaching and Technology. New York: Continuum.

Thomas, Michael \& Hayo Reinders. 2010b. "Deconstructing tasks and technology". In Thomas, M. \& H. Reinders (eds.), Task-based Language Teaching and Technology. New York: Continuum, 1-16.

Van den Branden, Kris, Koen Van Gorp \& Machteld Verhelst (eds.) 2007. Tasks in Action: Task-based language education from a classroom-based perspective. Newcastle: Cambridge Scholars Press.

Whyte, Shona. 1994. "The role of specialized knowledge in interlanguage variation: The discourse domain hypothesis". Unpublished doctoral dissertation, Indiana University, Bloomington. 
Whyte, Shona. 1995. "Specialist knowledge and interlanguage development: A discourse domain approach to text construction”. Studies in Second Language Acquisition 17/2, 153-183.

Willis, Jane. 1996. A Framework for Task-Based Learning. Essex, UK: Longman.

Willis, David \& Jane Willis. 2007. Doing Task-based Teaching. Oxford: Oxford University Press.

Young, Richard. 1999. "Sociolinguistic approaches to SLA". Annual Review of Applied Linguistics 19, 105-132.

\section{ABSTRACTS}

This paper examines teaching English for Specific Purposes (ESP) to French graduate students in business, science education, and social science research. It takes a discourse domain perspective (Selinker \& Douglas 1985; Whyte 1995) on interlanguage development according to which learners' expert knowledge and investment in their fields of study affects language learning and use. The study applies a task-based approach (Long 1989; Ellis 2003; Guichon \& Nicolaev 2011) to curriculum design, using the methodological principles developed for language teaching with technology by Doughty and Long (2003) to the design and implementation of the three ESP courses. The paper discusses classroom activities, peer and teacher feedback, and presents postcourse evaluation data in support of task-based learning, in order to draw nuanced practical and theoretical conclusions on this approach to ESP teaching.

Dans cet article, l'auteur étudie l'enseignement de l'anglais de spécialité (ASP) dans des cours de niveau master et doctorat dans les domaines de la gestion, de l'enseignement de la physiquechimie, et de la recherche en sciences sociales. Elle part de l'hypothèse de «domaines de discours » (Selinker \& Douglas 1985 ; Whyte 1995) selon laquelle les connaissances spécifiques des apprenants ainsi que leur engagement dans la discipline influent sur l'utilisation et l'évolution de la langue seconde. Elle adopte une approche d'apprentissage par tâches (Long 1989 ; Ellis 2003 ; Guichon \& Nicolaev 2011) en appliquant les principes méthodologiques proposés par Doughty et Long (2003) pour l'enseignement des langues avec les technologies à la conception et à la mise en œuvre de trois types d'enseignement d'ASP. L'article démontre l'intérêt des principes d'apprentissage par tâches pour la construction de curricula et pour la mise en place d'activités d'apprentissage, puis tire des conclusions sur les retombées pratiques aussi bien que théoriques.

\section{INDEX}

Keywords: curriculum, discourse domain, ESP, ICT, methodology, language acquisition, taskbased language teaching, TBLT

Mots-clés: acquisition des langues, anglais de spécialité, curriculum, didactique, domaine de discours, méthodologie, tâche, TICE

\section{AUTHOR}

\section{SHONA WHYTE}

Shona Whyte holds a PhD in Linguistics from Indiana University Bloomington and teaches and researches EFL, TEFL and SLA in the English department at the University of Nice-Sophia Antipolis. She has published on interactive technologies in the language class (young learners, 
teacher education) and is currently leading the French team in an EU-funded project on interactive whiteboards for language teaching and learning. She is a member of the LiDida group in the BCL research laboratory (UMR 7320 Bases, Corpus, Langage). whyte@unice.fr 